\title{
Dalton

\section{Reactivity of Ir(III) carbonyl complexes with water: alternative by-product formation pathways in catalytic methanol carbonylation †¥}

\author{
Paul I. P. Elliott, $\S^{a}$ Susanne Haak, ${ }^{a}$ Anthony J. H. M. Meijer, ${ }^{a}$ Glenn J. Sunley $^{\mathrm{b}}$ and \\ Anthony Haynes*a
}

\begin{abstract}
The reactions of water with a number of iridium(III) complexes relevant to the mechanism for catalytic methanol carbonylation are reported. The iridium acetyl, $\left[\operatorname{lr}(\mathrm{CO})_{2} \mathrm{l}_{3}(\mathrm{COMe})\right]^{-}$, reacts with water under mild conditions to release $\mathrm{CO}_{2}$ and $\mathrm{CH}_{4}$, rather than the expected acetic acid. Isotopic labeling and kinetic experiments are consistent with a mechanism involving nucleophilic attack by water on a terminal $\mathrm{CO}$ ligand of $\left[\operatorname{Ir}(\mathrm{CO})_{2} \mathrm{l}_{3}(\mathrm{COMe})\right]^{-}$to give an (undetected) hydroxycarbonyl species. Subsequent decarboxylation and elimination of methane gives $\left[\operatorname{Ir}(\mathrm{CO})_{2} \mathrm{I}_{2}\right]^{-}$. Similar reactions with water are observed for $\left[\operatorname{Ir}(\mathrm{CO})_{2} \mathrm{I}_{3} \mathrm{Me}\right]^{-},\left[\left.\operatorname{Ir}(\mathrm{CO})_{2}(\mathrm{NCMe})\right|_{2}(\mathrm{COMe})\right]$ and $\left[\operatorname{Ir}(\mathrm{CO})_{3} \mathrm{I}_{2} \mathrm{Me}\right]$ with the neutral complexes exhibiting markedly higher rates. The results demonstrate that $\mathrm{CO}_{2}$ formation during methanol carbonylation is not restricted to the conventional water gas shift mechanism mediated by $\left[\operatorname{Ir}(\mathrm{CO})_{2} \mathrm{I}_{4}\right]^{-}$or $\left[\operatorname{Ir}(\mathrm{CO})_{3} \mathrm{l}_{3}\right]$, but can arise directly from key organo-iridium(III) intermediates in the carbonylation cycle. An alternative pathway for methane formation not involving the intermediacy of $\mathrm{H}_{2}$ is also suggested. A mechanism is proposed for the conversion $\mathrm{MeOH}+\mathrm{CO} \rightarrow \mathrm{CO}_{2}+\mathrm{CH}_{4}$, which may account for the similar rates of formation of the two gaseous by-products during iridium-catalysed methanol carbonylation.
\end{abstract}

Received 1st August 2013,

Accepted 17th September 2013

DOI: $10.1039 / c 3 d t 52092 g$

www.rsc.org/dalton
Cativa $^{\mathrm{TM}}$ process has a number of benefits compared to the rhodium-based process, including high activity and catalyst stability at low water concentrations. The iridium-based catalyst also gives reduced levels of liquid by-products and improved yield based on CO.

For both the rhodium- and iridium-based processes, however, a significant side reaction is the water-gas-shift (WGS) reaction (eqn (1)). ${ }^{1,16}$ A mechanism proposed by Forster ${ }^{17}$ for the Ir-catalysed WGS reaction is shown in Scheme 1, involving anionic and neutral cycles. Oxidation of $\left[\operatorname{Ir}(\mathrm{CO})_{2} \mathrm{I}_{2}\right]^{-}$or $\left[\operatorname{Ir}(\mathrm{CO})_{3} \mathrm{I}\right]$ by $\mathrm{HI}$ leads to a hydride complex that can react with a second equivalent of $\mathrm{HI}$ to release $\mathrm{H}_{2}$. Carbon dioxide then results from nucleophilic attack by water on an anionic or neutral Ir(III) iodocarbonyl complex, with reduction of the iridium back to $\operatorname{Ir}(\mathrm{I})$.

Scheme 1 Proposed cycles for the iridium/iodide catalysed WGS reaction.

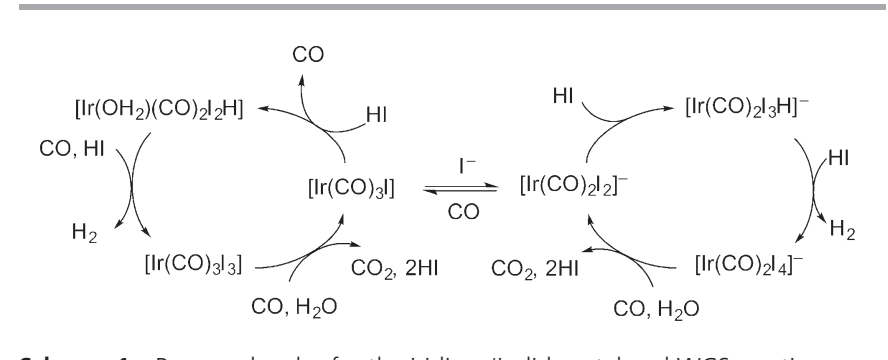

\footnotetext{
${ }^{a}$ Department of Chemistry, University of Sheffield, Sheffield, S3 7HF, UK. E-mail: a.haynes@sheffield.ac.uk

${ }^{b} B P$ Chemicals Limited, Hull Research and Technology Centre, Saltend, Hull, HU12 8DS, UK

$\dagger$ Dedicated to Professor David Cole-Hamilton on the occasion of his retirement and for his outstanding contribution to transition metal catalysis.

†Electronic supplementary information (ESI) available. See DOI: 10.1039/ c3dt52092g

$\S$ Current address: Department of Chemical \& Biological Sciences, University of Huddersfield, Huddersfield, UK.
} 


$$
\mathrm{H}_{2} \mathrm{O}+\mathrm{CO} \rightarrow \mathrm{CO}_{2}+\mathrm{H}_{2}
$$

The hydrogen that is formed in the WGS reaction can participate in other side reactions such as methane formation via the formal hydrogenolysis of methanol (eqn (2)). When coupled with the WGS reaction this results in the net conversion of methanol and $\mathrm{CO}$ into methane and $\mathrm{CO}_{2}$ (eqn (3)). ${ }^{18}$ Data reported previously show that $\mathrm{CO}_{2}$ and $\mathrm{CH}_{4}$ are formed at comparable rates ( $c a .1 \%$ of the carbonylation rate) during $\mathrm{Ru}$ promoted Ir-catalysed methanol carbonylation. ${ }^{14}$

$$
\begin{aligned}
& \mathrm{MeOH}+\mathrm{H}_{2} \rightarrow \mathrm{CH}_{4}+\mathrm{H}_{2} \mathrm{O} \\
& \mathrm{MeOH}+\mathrm{CO} \rightarrow \mathrm{CO}_{2}+\mathrm{CH}_{4}
\end{aligned}
$$

We have shown previously that methane can be formed from the iridium methyl complex, $\left[\operatorname{Ir}(\mathrm{CO})_{2} \mathrm{I}_{3} \mathrm{Me}\right]^{-}$, by reaction with $\mathrm{H}_{2}$ (eqn (4)) or on heating in carboxylic acid solvents, presumably by protonolysis of the methyl ligand (eqn (5)). ${ }^{19}$

$$
\begin{gathered}
{\left[\operatorname{Ir}(\mathrm{CO})_{2} \mathrm{I}_{3} \mathrm{Me}\right]^{-}+\mathrm{H}_{2} \rightarrow\left[\operatorname{Ir}(\mathrm{CO})_{2} \mathrm{I}_{3} \mathrm{H}\right]^{-}+\mathrm{CH}_{4}} \\
{\left[\operatorname{Ir}(\mathrm{CO})_{2} \mathrm{I}_{3} \mathrm{Me}\right]^{-}+\mathrm{RCO}_{2} \mathrm{H} \rightarrow\left[\operatorname{Ir}(\mathrm{CO})_{2} \mathrm{I}_{3}\left(\mathrm{O}_{2} \mathrm{CR}\right)\right]^{-}+\mathrm{CH}_{4}}
\end{gathered}
$$

Since $\left[\operatorname{Ir}(\mathrm{CO})_{2} \mathrm{I}_{3} \mathrm{Me}\right]^{-}$has been identified as the resting state for the iridium catalyst, ${ }^{14,17,20}$ its reactions with $\mathrm{H}_{2}$ (from the WGS reaction) or acetic acid (the major component of the reaction medium) can be considered plausible pathways for the formation of methane during catalytic carbonylation. In this paper we present results that suggest an alternative mechanism for formation of methane and $\mathrm{CO}_{2}$ from iridium species that participate in the carbonylation cycle. These reactions involve nucleophilic attack by water on a carbonyl ligand of an iridium methyl or acetyl complex, and occur without the intermediacy of $\mathrm{H}_{2}$.

\section{Results and discussion}

\section{Reactivity of $\left[\operatorname{Ir}(\mathrm{CO})_{2} \mathrm{I}_{3}(\mathrm{COMe})\right]^{-}$with water}

Mechanistic cycles for iridium-catalysed methanol carbonylation generally depict the $\operatorname{Ir}(\mathrm{III})$ acetyl complex $\left[\operatorname{Ir}(\mathrm{CO})_{2} \mathrm{I}_{3}\right.$ $(\mathrm{COMe})]^{-}$reacting with water to eliminate acetic acid (eqn (6)), either directly or via initial reductive elimination of acetyl iodide and subsequent hydrolysis.

$$
\left[\operatorname{Ir}(\mathrm{CO})_{2} \mathrm{I}_{3}(\mathrm{COMe})\right]^{-}+\mathrm{H}_{2} \mathrm{O} \rightarrow\left[\operatorname{Ir}(\mathrm{CO})_{2} \mathrm{I}_{2}\right]^{-}+\mathrm{MeCO}_{2} \mathrm{H}+\mathrm{HI}
$$

The initial intention of the present study was to investigate the kinetics of this product-forming step of the carbonylation cycle. The isolation and structural characterization of both cis, fac and trans,mer isomers of $\left[\operatorname{Ir}(\mathrm{CO})_{2} \mathrm{I}_{3}(\mathrm{COMe})\right]^{-}$have been reported previously. ${ }^{20-23}$ When the reaction of the cis,fac isomer with water was monitored spectroscopically under mild conditions ( $\mathrm{MeCN}, 42{ }^{\circ} \mathrm{C}$ ) an unexpected outcome resulted. In a typical series of IR spectra (Fig. 1) the decay of the reactant $\nu$ (CO) absorptions at 2110, 2062 and $1658 \mathrm{~cm}^{-1}$ is accompanied by the growth of new bands at 2046 and $1968 \mathrm{~cm}^{-1}$, assigned to $\left[\operatorname{Ir}(\mathrm{CO})_{2} \mathrm{I}_{2}\right]^{-}$, consistent with the

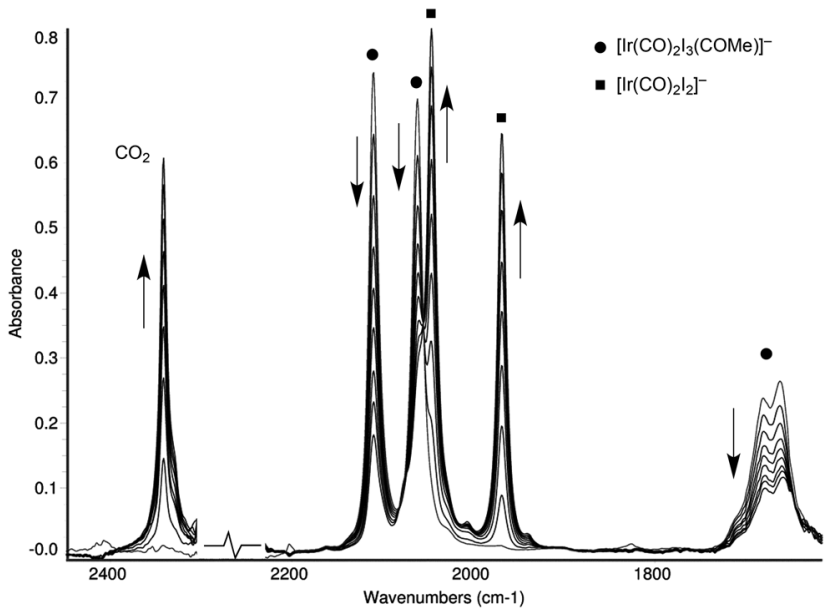

Fig. 1 IR spectra recorded during the reaction of cis, $\mathrm{fac}-\left[\mathrm{Ir}(\mathrm{CO})_{2} \mathrm{I}_{3}(\mathrm{COMe})\right]^{-}$(as its $\mathrm{Ph}_{4} \mathrm{As}^{+}$salt $)$with $\mathrm{H}_{2} \mathrm{O}\left(0.56 \mathrm{~mol} \mathrm{dm}^{-3}\right)$ in $\mathrm{MeCN}$ at $42{ }^{\circ} \mathrm{C}$. The region around $2300 \mathrm{~cm}^{-1}$ is masked due to the strong solvent $\nu(\mathrm{CN})$ band.

expected reaction (eqn (6)). However the IR spectra did not indicate the formation of any acetic acid in the region of $1750 \mathrm{~cm}^{-1}$. Instead, inspection of the region between 2200 and $2500 \mathrm{~cm}^{-1}$ revealed the appearance of an intense new band at $2342 \mathrm{~cm}^{-1}$ characteristic of the formation of $\mathrm{CO}_{2}$. The formation of $\mathrm{CO}_{2}$ in this reaction is indicative of nucleophilic attack by water on coordinated CO. Furthermore, since a dicarbonyl species is formed and no organic acyl product is detected, the observations are consistent with concomitant decarbonylation of the acetyl ligand according to the reaction stoichiometry shown in eqn (7). The analogous reaction of trans, mer- $\left[\operatorname{Ir}(\mathrm{CO})_{2} \mathrm{I}_{3}(\mathrm{COMe})\right]^{-}$with water under the same conditions was also found to result in $\mathrm{CO}_{2}$ formation.

$$
\left[\operatorname{Ir}(\mathrm{CO})_{2} \mathrm{I}_{3}(\mathrm{COMe})\right]^{-}+\mathrm{H}_{2} \mathrm{O} \rightarrow\left[\operatorname{Ir}(\mathrm{CO})_{2} \mathrm{I}_{2}\right]^{-}+\mathrm{CO}_{2}+\mathrm{CH}_{4}+\mathrm{HI}
$$

Further evidence is provided by the detection of methane. In an NMR tube experiment, a solution of cis,fac$\left[\operatorname{Ir}(\mathrm{CO})_{2} \mathrm{I}_{3}(\mathrm{COMe})\right]^{-}$in $\mathrm{d}_{3}-\mathrm{MeCN}$ containing water $(1 \% \mathrm{v} / \mathrm{v})$ was heated to $35{ }^{\circ} \mathrm{C}$ for 2 days, resulting in the appearance of a ${ }^{1} \mathrm{H}$ resonance at $\delta 0.19$, assigned to dissolved methane. When the experiment was repeated with the ${ }^{13} \mathrm{C}$-labelled analogue, $\left[\operatorname{Ir}(\mathrm{CO})_{2} \mathrm{I}_{3}\left(\mathrm{CO}^{13} \mathrm{CH}_{3}\right)\right]^{-}$, a doublet $\left(J_{\mathrm{CH}}=125.5 \mathrm{~Hz}\right)$ was observed at the same chemical shift corresponding to the formation of ${ }^{13} \mathrm{CH}_{4}$.

The results presented above do not distinguish whether the $\mathrm{CO}_{2}$ is derived from one of the terminal $\mathrm{CO}$ ligands or the acetyl carbonyl of $\left[\operatorname{Ir}(\mathrm{CO})_{2} \mathrm{I}_{3}(\mathrm{COMe})\right]^{-}$. In principle, nucleophilic attack by water on a CO ligand could occur either before or after the decarbonylation step. We therefore undertook isotopic labeling experiments to elucidate the mechanism further. We first sought to prove the participation of added water in the formation of $\mathrm{CO}_{2}$ using $c a \cdot 10 \%{ }^{18} \mathrm{O}$ enriched water. The experiment was performed using THF as solvent to avoid interference from the strong solvent $\nu(\mathrm{CN})$ absorption encountered with acetonitrile. A spectrum recorded during 


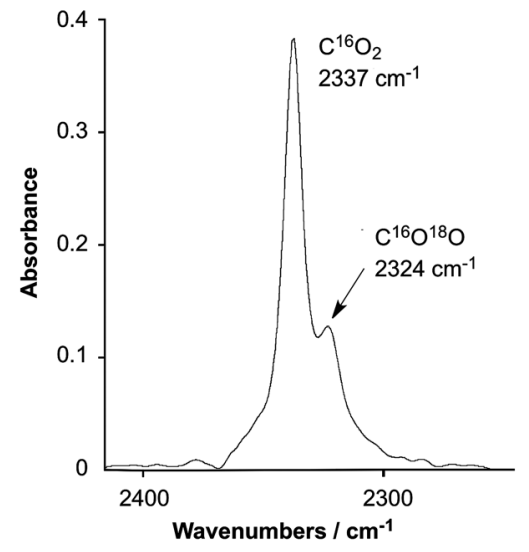

Fig. 2 IR absorptions for $\mathrm{CO}_{2}$ formed in the reaction of cis,fac$\left[\operatorname{Ir}(\mathrm{CO})_{2} \mathrm{l}_{3}(\mathrm{COMe})\right]^{-}$with water $\left(10.3 \%{ }^{18} \mathrm{O}\right.$ labelled $)$ in $\mathrm{THF}$ at $42{ }^{\circ} \mathrm{C}$ showing bands for $\mathrm{C}^{16} \mathrm{O}_{2}$ and $\mathrm{C}^{16} \mathrm{O}^{18} \mathrm{O}$.

this reaction (Fig. 2) shows the band for $\mathrm{C}^{16} \mathrm{O}_{2}$ at $2337 \mathrm{~cm}^{-1}$ as well as a weaker band at $2324 \mathrm{~cm}^{-1}$ corresponding to $\mathrm{C}^{16} \mathrm{O}^{18} \mathrm{O}$. The formation of this isotopologue provides direct evidence of the involvement of added water in the formation of $\mathrm{CO}_{2}$.

To distinguish whether a terminal or acyl carbonyl is the origin of the observed $\mathrm{CO}_{2}$, a ${ }^{13} \mathrm{C}$-labelled sample of cis,fac$\left[\operatorname{Ir}(\mathrm{CO})_{2} \mathrm{I}_{3}(\mathrm{COMe})\right]^{-}$was prepared. Initially the methyl complex $\left[\operatorname{Ir}\left({ }^{*} \mathrm{CO}\right)_{2} \mathrm{I}_{3} \mathrm{Me}\right]^{-}$was synthesised with $c a .65 \%{ }^{13} \mathrm{C}$ enrichment of the $\mathrm{CO}$ ligands. Carbonylation of this complex using nonenriched $\mathrm{CO}(10$ bar) resulted in the acetyl complex $\left[\operatorname{Ir}(\mathrm{CO})_{2} \mathrm{I}_{3}\left({ }^{*} \mathrm{COMe}\right)\right]^{-}$in which ca. $30-35 \%{ }^{13} \mathrm{C}$ label was retained in the acetyl carbonyl position but the label was largely lost from the terminal carbonyl sites ( $c a .5 \%$ as judged from the IR spectrum). A series of IR spectra recorded during the reaction of this labelled compound with water in THF is shown in Fig. 3. It is clear that the $\mathrm{CO}_{2}$ formed is largely unlabelled, with only a weak band due to ${ }^{13} \mathrm{CO}_{2}$. This matches the level of ${ }^{13} \mathrm{C}$ enrichment in the terminal $\mathrm{CO}$ ligands of the reactant and proves that the $\mathrm{CO}_{2}$ is derived from a terminal $\mathrm{CO}$ ligand of $\left[\operatorname{Ir}(\mathrm{CO})_{2} \mathrm{I}_{3}\left({ }^{*} \mathrm{COMe}\right)\right]^{-}$. Consistent with this, the IR

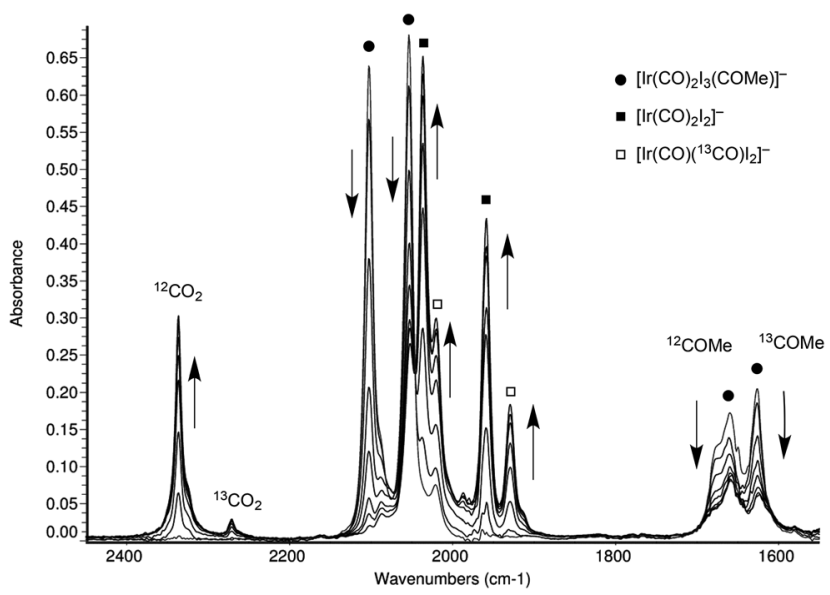

Fig. 3 Series of IR spectra during the reaction of cis, fac- $\left[\mathrm{Ir}(\mathrm{CO})_{2} \mathrm{I}_{3}\left({ }^{*} \mathrm{COMe}\right)\right]^{-}$ with water $\left(0.56 \mathrm{~mol} \mathrm{dm}^{-3}\right)$ in $\mathrm{THF}$ at $42{ }^{\circ} \mathrm{C}$.
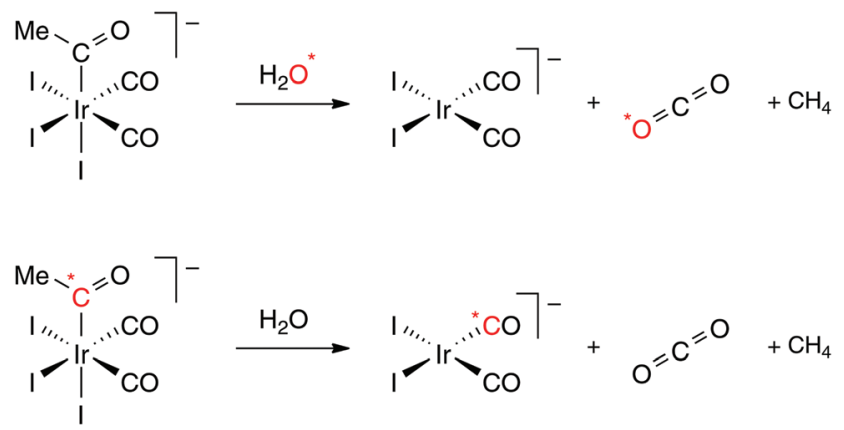

Scheme 2 Isotopic labelling experiments.

spectra indicate formation of a ca. 2:1 mixture of $\left[\operatorname{Ir}\left({ }^{12} \mathrm{CO}\right)_{2} \mathrm{I}_{2}\right]^{-}\left(2036,1958 \mathrm{~cm}^{-1}\right)$ and $\left[\operatorname{Ir}\left({ }^{12} \mathrm{CO}\right)\left({ }^{13} \mathrm{CO}\right) \mathrm{I}_{2}\right]^{-}(2020$, $1930 \mathrm{~cm}^{-1}$ ), indicating that the ${ }^{13} \mathrm{C}$ label from the acetyl group is retained as a terminal $\mathrm{CO}$ ligand in the product complex. The outcome of the labeling experiments is summarized in Scheme 2.

\section{Kinetics}

The kinetic behaviour of the reaction of cis, fac-[Ir(CO) $2_{2}^{-}$ $\left.\mathrm{I}_{3}(\mathrm{COMe})\right]^{-}$with water was assessed from plots of IR absorbance vs. time. Under pseudo-first order conditions (excess water), the decay of the $2110 \mathrm{~cm}^{-1}$ band for the reactant was fitted approximately by an exponential curve, although there was some deviation from ideal behaviour. This might arise from the change in acidity of the reaction solution with time, due to the release of HI according to eqn (6). A somewhat better fit to first order behaviour was found for the growth of the band due to $\mathrm{CO}_{2}$ at $2342 \mathrm{~cm}^{-1}$. Values of a pseudo first order rate constant, $k_{\mathrm{obs}}$, were therefore obtained by analysis of this absorption to determine the effect of water concentration. A plot of $k_{\text {obs }} v s .\left[\mathrm{H}_{2} \mathrm{O}\right]$ is reasonably linear (Fig. 4) with an intercept close to the origin, and the slope gives an estimated second order rate constant of $1.2( \pm 0.1) \times 10^{-4} \mathrm{dm}^{3} \mathrm{~mol}^{-1} \mathrm{~s}^{-1}$ at $42{ }^{\circ} \mathrm{C} .{ }^{24}$ The approximate second order kinetics are consistent with a bimolecular reaction between the iridium complex and water. A detailed kinetic study was not undertaken for the reaction of water with trans, mer $\left[\operatorname{Ir}(\mathrm{CO})_{2} \mathrm{I}_{3}(\mathrm{COMe})\right]^{-}$, but the rate

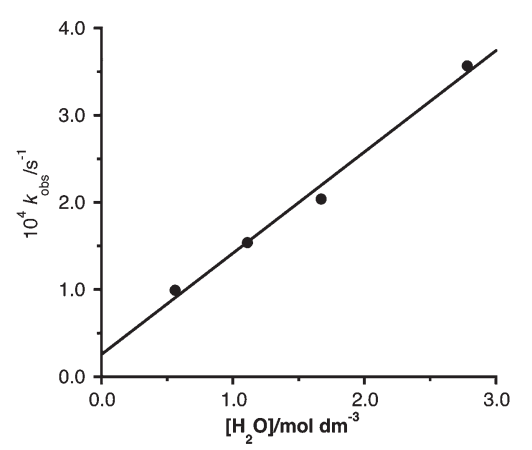

Fig. 4 Plot of $k_{\text {obs }}$ vs. $\left[\mathrm{H}_{2} \mathrm{O}\right]$ for reaction of $c i s, f a c-\left[\mathrm{Ir}(\mathrm{CO})_{2} \mathrm{I}_{3}(\mathrm{COMe})\right]^{-}$with water $\left(\mathrm{MeCN}, 42^{\circ} \mathrm{C}\right.$ ). 
for this isomer was found to be marginally slower than the cis, fac complex under the same conditions.

Since the observed reaction products implicate loss of an iodide ligand, we tested the effect of iodide salt on the rate. Addition of $\mathrm{Bu}_{4} \mathrm{NI}$ caused a modest promotional effect (e.g. by a factor of $c a .2$ at $0.15 \mathrm{M} \mathrm{Bu}_{4} \mathrm{NI}$ ). The results are therefore consistent with a direct nucleophilic attack by water on a $\mathrm{CO}$ ligand of the anionic reactant complex, since a mechanism involving initial iodide dissociation would result in rate inhibition by iodide salt.

\section{Reactivity of other anionic Ir(III) complexes}

In situ IR spectroscopy has identified $\left[\operatorname{Ir}(\mathrm{CO})_{2} \mathrm{I}_{3} \mathrm{Me}\right]^{-}$as the dominant catalyst species during catalytic methanol carbonylation and $\left[\operatorname{Ir}(\mathrm{CO})_{2} \mathrm{I}_{4}\right]^{-}$can also accumulate as a resting state in the competing WGS reaction. ${ }^{14,17,20}$ The reactions of both of these anionic complexes with water have been studied under comparable conditions to those used for $\left[\operatorname{Ir}(\mathrm{CO})_{2} \mathrm{I}_{3}(\mathrm{COMe})\right]^{-}$ (42 ${ }^{\circ} \mathrm{C}$ in $\mathrm{MeCN}$ or THF). In each case $\mathrm{CO}_{2}$ formation was apparent from the growth of an IR band at $c a .2340 \mathrm{~cm}^{-1}$. Reactions using ${ }^{13} \mathrm{CO}$ enriched $\left[\operatorname{Ir}(\mathrm{CO})_{2} \mathrm{I}_{3} \mathrm{Me}\right]^{-}$or $\left[\operatorname{Ir}(\mathrm{CO})_{2} \mathrm{I}_{4}\right]^{-}$ gave ${ }^{12} \mathrm{CO}_{2}$ and ${ }^{13} \mathrm{CO}_{2}$ in the expected ratio based on the level of isotopic enrichment of the metal complex. The IR spectra again indicate formation of $\left[\operatorname{Ir}(\mathrm{CO})_{2} \mathrm{I}_{2}\right]^{-}$, although the maximum possible yield of this dicarbonyl is $50 \%$ in the absence of added CO (assuming conversion of one CO ligand per reactant complex to $\mathrm{CO}_{2}$ ). The reactions shown in eqn (8) and (9) include a non-carbonyl iridium(I) side-product, " $\left[\operatorname{IrI}_{2}\right]^{-}$" to account for this. In the presence of added CO this would be expected to be converted into $\left[\operatorname{Ir}(\mathrm{CO})_{2} \mathrm{I}_{2}\right]^{-}$.

$$
\begin{aligned}
{\left[\operatorname{Ir}(\mathrm{CO})_{2} \mathrm{I}_{3} \mathrm{Me}\right]^{-}+\mathrm{H}_{2} \mathrm{O} \rightarrow } & 1 / 2\left[\operatorname{Ir}(\mathrm{CO})_{2} \mathrm{I}_{2}\right]^{-}+1 / 2 \text { “[ }\left[\operatorname{IrI}_{2}\right]^{-»} \\
& +\mathrm{CO}_{2}+\mathrm{CH}_{4}+\mathrm{HI} \\
{\left[\operatorname{Ir}(\mathrm{CO})_{2} \mathrm{I}_{4}\right]^{-}+\mathrm{H}_{2} \mathrm{O} \rightarrow } & \left.1 / 2\left[\operatorname{Ir}(\mathrm{CO})_{2} \mathrm{I}_{2}\right]^{-}+1 / 2 \text { “[ } \operatorname{IrI}_{2}\right]^{-»} \\
+ & \mathrm{CO}_{2}+2 \mathrm{HI}
\end{aligned}
$$

The reactions with water observed for the series of complexes $\left[\operatorname{Ir}(\mathrm{CO})_{2} \mathrm{I}_{3} \mathrm{R}\right]^{-}(\mathrm{R}=\mathrm{I}, \mathrm{Me}, \mathrm{COMe})$, demonstrate that $\mathrm{CO}_{2}$ formation during Ir-catalysed methanol carbonylation is not restricted to the conventional WGS cycle involving attack by water on $\left[\operatorname{Ir}(\mathrm{CO})_{2} \mathrm{I}_{4}\right]^{-}$or $\left[\operatorname{Ir}(\mathrm{CO})_{3} \mathrm{I}_{3}\right]$. Susceptibility to nucleophilic attack by water clearly extends to other Ir(III) complexes and can be coupled with methane formation when $\mathrm{R}=\mathrm{Me}$ or COMe.

\section{Reactivity of neutral Ir(III) complexes}

Mechanistic investigations of iridium-catalysed methanol carbonylation have established the participation of neutral as well as anionic complexes. ${ }^{17,20,25,26}$ We therefore extended our study to neutral Ir(III) acetyl and methyl complexes, which are expected to be more electrophilic than the anionic species. Abstraction of iodide from cis, fac $\left[\operatorname{Ir}(\mathrm{CO})_{2} \mathrm{I}_{3}(\mathrm{COMe})\right]^{-}$in acetonitrile was accomplished by reaction with a small excess of $\mathrm{InI}_{3}$, as previously reported for the analogous methyl complex, cis, fac- $\left[\operatorname{Ir}(\mathrm{CO})_{2} \mathrm{I}_{3} \mathrm{Me}\right]^{-20}$ The IR spectrum of the product in
MeCN showed $\nu(\mathrm{CO})$ bands at 2136, 2094 and $1701 \mathrm{~cm}^{-1}$. The shift of each absorption to high frequency with respect to the anionic precursor is consistent with loss of an iodide ligand to give a solvated neutral complex, $\left[\operatorname{Ir}(\mathrm{CO})_{2}(\mathrm{NCMe}) \mathrm{I}_{2}(\mathrm{COMe})\right]$, by analogy with the previously reported $\left[\operatorname{Ir}(\mathrm{CO})_{2}(\mathrm{NCMe}) \mathrm{I}_{2} \mathrm{Me}\right]{ }^{20,27}$ Addition of water to this solution resulted in formation of $\mathrm{CO}_{2}$ and absorptions at 2077 and $2006 \mathrm{~cm}^{-1}$ that are assigned to $\left[\operatorname{Ir}(\mathrm{CO})_{2} \mathrm{I}(\mathrm{NCMe})\right]^{27}$ along with a very small amount of $\left[\operatorname{Ir}(\mathrm{CO})_{2} \mathrm{I}_{2}\right]^{-}$. Hence, the results are analogous to those for the anionic system, and accord with the reaction in eqn (10). A detailed kinetic study was not undertaken, but a pseudo-first order rate constant of $1.04 \times 10^{-3} \mathrm{~s}^{-1}$ was measured at $34{ }^{\circ} \mathrm{C}$, which is an order of magnitude greater than that for $\left[\operatorname{Ir}(\mathrm{CO})_{2} \mathrm{I}_{3}(\mathrm{COMe})\right]^{-}$under the same conditions.

$$
\begin{aligned}
& {\left[\operatorname{Ir}(\mathrm{CO})_{2}(\mathrm{NCMe}) \mathrm{I}_{2}(\mathrm{COMe})\right]+\mathrm{H}_{2} \mathrm{O}} \\
& \quad \rightarrow\left[\operatorname{Ir}(\mathrm{CO})_{2}(\mathrm{NCMe}) \mathrm{I}\right]+\mathrm{CO}_{2}+\mathrm{CH}_{4}+\mathrm{HI}
\end{aligned}
$$

Another significant species in the catalytic carbonylation mechanism is the methyl complex $\left[\operatorname{Ir}(\mathrm{CO})_{3} \mathrm{I}_{2} \mathrm{Me}\right]$, formed upon substitution of an iodide ligand in $\left[\operatorname{Ir}(\mathrm{CO})_{2} \mathrm{I}_{3} \mathrm{Me}\right]^{-}$by $\mathrm{CO}$. We have previously characterised this tricarbonyl as the fac,cis isomer using in situ high pressure IR and NMR spectroscopy. ${ }^{26}$ This neutral species undergoes migratory CO insertion much more readily than the anion, explaining the promotional effect on the carbonylation process of certain species that bind iodide. $^{20}$

In the present investigation, high pressure IR spectroscopy was used to probe the reactivity of $\left[\operatorname{Ir}(\mathrm{CO})_{3} \mathrm{I}_{2} \mathrm{Me}\right]$ towards water. The tricarbonyl was generated from the dimer, $\left[\operatorname{Ir}(\mathrm{CO})_{2} \mathrm{I}_{2} \mathrm{Me}\right]_{2}$ under 20 bar $\mathrm{CO}$ in $\mathrm{CH}_{2} \mathrm{Cl}_{2}$-THF $(3: 1)$ and identified by its $\nu$ (CO) bands at 2156, 2116 and $2098 \mathrm{~cm}^{-1}$. In the presence of water, at ambient temperature, these absorptions decayed and new bands grew at 2072 and $2042 \mathrm{~cm}^{-1}$, corresponding to the $\operatorname{Ir}(\mathrm{I})$ tricarbonyl, $\left[\operatorname{Ir}(\mathrm{CO})_{3} \mathrm{I}\right]$. The eventual IR spectrum was more complex and also indicated formation of the anionic species, $\left[\operatorname{Ir}(\mathrm{CO})_{2} \mathrm{I}_{3} \mathrm{Me}\right]^{-}$and $\left[\operatorname{Ir}(\mathrm{CO})_{2} \mathrm{I}_{2}\right]^{-}$(vide infra). GC-MS analysis of the headspace of the IR cell at the end of the reaction demonstrated the presence of methane and $\mathrm{CO}_{2}$ but no organic acetyl products (e.g. acetic acid) were detected. Isotopic labeling experiments confirmed that the iridium complex is the source of both gaseous products; $\mathrm{CD}_{3} \mathrm{H}$ was generated from the $\mathrm{CD}_{3}$ labelled complex and a significant quantity of ${ }^{13} \mathrm{CO}_{2}$ resulted from the ${ }^{13} \mathrm{CO}$-enriched complex, despite the large excess of natural abundance $\mathrm{CO}$ used. The observations are therefore consistent with eqn (11). Since HI is formed during the reaction, this can act as a source of iodide that can be scavenged by either $\left[\operatorname{Ir}(\mathrm{CO})_{3} \mathrm{I}_{2} \mathrm{Me}\right]$ or $\left[\operatorname{Ir}(\mathrm{CO})_{3} \mathrm{I}\right]$ to give the anions $\left[\operatorname{Ir}(\mathrm{CO})_{2} \mathrm{I}_{3} \mathrm{Me}\right]^{-}$or $\left[\operatorname{Ir}(\mathrm{CO})_{2} \mathrm{I}_{2}\right]^{-}$, as observed by IR spectroscopy.

$$
\left[\operatorname{Ir}(\mathrm{CO})_{3} \mathrm{I}_{2} \mathrm{Me}\right]+\mathrm{H}_{2} \mathrm{O}+\mathrm{CO} \rightarrow\left[\operatorname{Ir}(\mathrm{CO})_{3} \mathrm{I}\right]+\mathrm{CO}_{2}+\mathrm{CH}_{4}+\mathrm{HI}
$$

Kinetic data were obtained by analyzing the exponential decay of the high frequency $\nu(\mathrm{CO})$ band of $\left[\operatorname{Ir}(\mathrm{CO})_{3} \mathrm{I}_{2} \mathrm{Me}\right]$ at $2157 \mathrm{~cm}^{-1}$ to give values of a pseudo-first order rate constant, $k_{\text {obs }}$. A plot of $k_{\text {obs }} v s$. [ $\mathrm{H}_{2} \mathrm{O}$ ] (Fig. 5) showed an approximate 


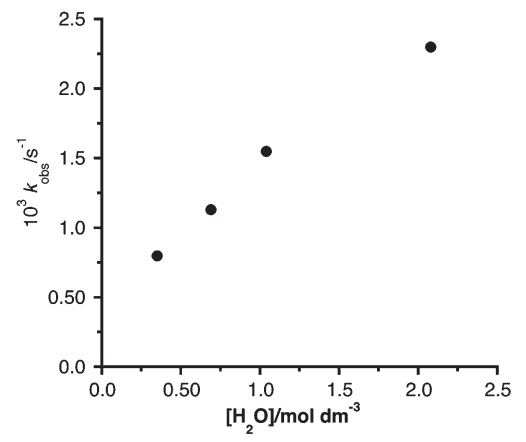

Fig. 5 Plot of $k_{\text {obs }} v s$. $\left[\mathrm{H}_{2} \mathrm{O}\right]$ for the reaction of $\left[\mathrm{Ir}(\mathrm{CO})_{3} \mathrm{I}_{2} \mathrm{Me}\right]$ with water in $3: 1$ $\mathrm{CH}_{2} \mathrm{Cl}_{2}-\mathrm{THF}, 20$ bar $\mathrm{CO}$ at $23^{\circ} \mathrm{C}$.

linear dependence on water concentration. The non-zero intercept may arise from contributions to the measured $k_{\text {obs }}$ values from side reactions such as those noted above involving $\mathrm{HI}$. Kinetic measurements were also made for reactions using $\mathrm{D}_{2} \mathrm{O}$ and reveal a small kinetic isotope effect, $k_{\mathrm{H}} / k_{\mathrm{D}}$ of $c a$. 1.3. This is similar to the value reported previously for the reaction of $\left[\operatorname{TpIr}(\mathrm{CO})_{2}\right]$ with water $\left(\mathrm{Tp}=\mathrm{HBpz}_{3}, \mathrm{pz}=\right.$ pyrazolyl $) .{ }^{28}$ The reactivity of $\left[\operatorname{Ir}(\mathrm{CO})_{3} \mathrm{I}_{2} \mathrm{Me}\right]$ is more than an order of magnitude higher than that reported above for $\left[\operatorname{Ir}(\mathrm{CO})_{2} \mathrm{I}_{3}(\mathrm{COMe})\right]^{-29}$ exemplifying the more facile nucleophilic attack by water on the carbonyl ligand of a neutral complex relative to an anion.

\section{Mechanism}

The results demonstrate that a range of Ir(III) complexes of relevance to catalytic methanol carbonylation react with water under relatively mild conditions to liberate $\mathrm{CO}_{2}$. For complexes that also contain an alkyl or acetyl ligand, formation of methane is also observed, resulting from (formal) proton transfer from water to a methyl moiety. Scheme 3 shows some alternative pathways for the reaction of $\left[\operatorname{Ir}(\mathrm{CO})_{2} \mathrm{I}_{3}(\mathrm{COMe})\right]^{-}$ with water. Initial nucleophilic attack by water on coordinated CO to form a hydroxycarbonyl complex B could occur with concerted loss of HI or in a stepwise manner via a di-anionic intermediate $\mathbf{A}$. The absence of rate inhibition on addition of iodide salt suggests that initial substitution of an iodide ligand by water is not required, although an alternative mechanism in which water coordinates by substitution of a $\mathrm{CO}$ ligand, followed by intramolecular nucleophilic attack, might be considered. Iridium(III) hydroxycarbonyl species have been reported previously, e.g. $\left[\mathrm{IrCl}_{2}\left(\mathrm{CO}_{2} \mathrm{H}\right)(\mathrm{CO}) \mathrm{L}_{2}\right]\left(\mathrm{L}=\mathrm{PMe}_{2} \mathrm{Ph}\right.$, $\left.\mathrm{AsMe}_{2} \mathrm{Ph}\right){ }^{30,31}\left[\mathrm{TpIr}(\mathrm{CO})\left(\mathrm{CO}_{2} \mathrm{H}\right) \mathrm{H}\right]\left(\mathrm{Tp}=\mathrm{HBpz}_{3}{ }^{-}\right.$or $\mathrm{HB}\left(3,5^{-}\right.$ $\left.\mathrm{Me}_{2} \mathrm{pz}_{3}{ }^{-}\right)^{28,32,33}$ and $\left[\mathrm{TpmIr}(\mathrm{CO})\left(\mathrm{CO}_{2} \mathrm{H}\right) \mathrm{H}\right]^{+}\left(\mathrm{Tpm}=\mathrm{HC}\left(3,5^{-}\right.\right.$ $\left.\left.\mathrm{Me}_{2} \mathrm{pz}\right)_{3}\right){ }^{34}$ The proposed reactive intermediate $\mathbf{B}$ has a vacant site that could mediate decarboxylation via $\beta$-H transfer to give a hydride, $\mathbf{C}$, followed by migration of methyl from $\mathrm{CO}$ to the Ir center and reductive elimination of methane from the hydrido methyl complex D. Alternatively, B might undergo migratory de-insertion to give $\mathbf{E}$, which could eliminate $\mathrm{CO}_{2}$ and methane in a stepwise fashion (via hydride $\mathbf{D}$ ) or in a concerted mechanism involving intramolecular proton transfer from the hydroxycarbonyl ligand to methyl. Similar mechanisms can be envisaged starting from the Ir methyl complexes $\left[\operatorname{Ir}(\mathrm{CO})_{2} \mathrm{I}_{3} \mathrm{Me}\right]^{-}$and $\left[\operatorname{Ir}(\mathrm{CO})_{3} \mathrm{I}_{2} \mathrm{Me}\right]$. For example nucleophilic attack by water on a carbonyl ligand of $\left[\operatorname{Ir}(\mathrm{CO})_{3} \mathrm{I}_{2} \mathrm{Me}\right]$ would lead to the hydroxycarbonyl intermediate $\mathbf{E}$ in Scheme 3.

Preliminary DFT calculations on intermediate $\mathbf{E}$ resulted in optimized structures with two alternative conformations of the hydroxycarbonyl ligand. The lowest energy conformation has a hydrogen-bonding interaction between the $\mathrm{CO}_{2} \mathrm{H}$ group and a cis iodide ligand as illustrated in Fig. 6a. An isomer of $\mathbf{E}$ with methyl and hydroxycarbonyl ligands mutually trans was calculated to be $c a .47 \mathrm{~kJ} \mathrm{~mol}^{-1}$ higher in energy. A transition state for H-transfer to the methyl ligand was located (Fig. 6b) with a calculated $\Delta G_{298}^{\ddagger}$ (relative to the lowest energy conformer of $\mathbf{E}$ ) of $118 \mathrm{~kJ} \mathrm{~mol}^{-1}$ (in the gas phase) or $109 \mathrm{~kJ} \mathrm{~mol}^{-1}$ (using the

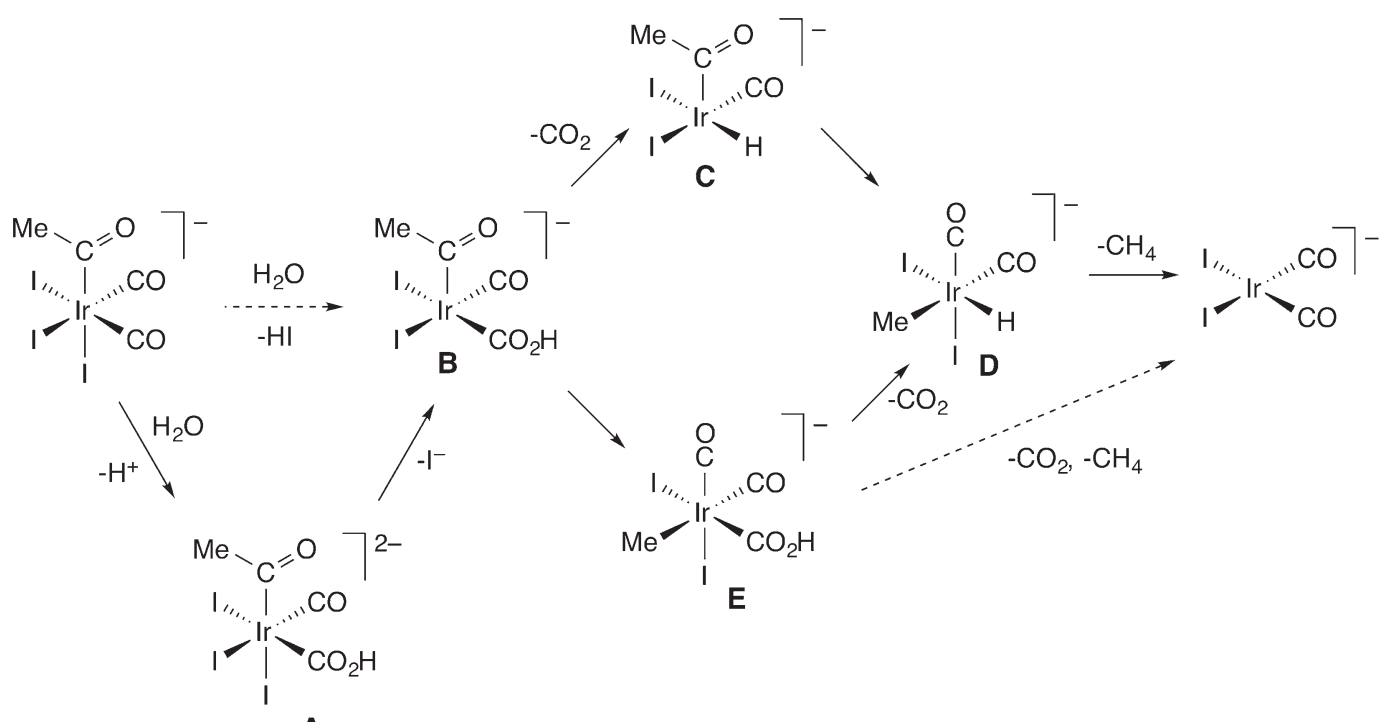

A

Scheme 3 Possible mechanisms for reaction of $c i s, f a c-\left[\operatorname{Ir}(\mathrm{CO})_{2} \mathrm{l}_{3}(\mathrm{COMe})\right]^{-}$with water. 
(a)

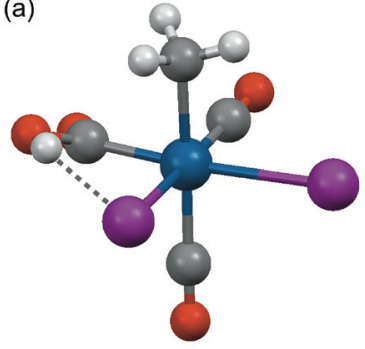

(b)

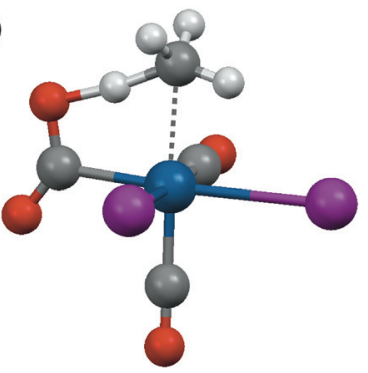

Fig. 6 DFT optimized structures for (a) complex $\mathbf{E},\left[\left.\operatorname{Ir}(\mathrm{CO})_{2}\left(\mathrm{CO}_{2} \mathrm{H}\right)\right|_{2} \mathrm{Me}\right]^{-}$and (b) transition state for $\mathrm{H}$ transfer to the methyl ligand.

PCM solvation model with acetonitrile as solvent). The transition state exhibits lengthening of both the Ir- $\mathrm{CH}_{3}$ and Ir$\mathrm{CO}_{2} \mathrm{H}$ bonds (by $c a .0 .22$ and $0.10 \AA$ respectively) compared to complex E. Calculations were also carried out for a neutral 5-coordinate analogue of $\mathbf{E}$ with the iodide ligand trans to $\mathrm{CO}_{2} \mathrm{H}$ omitted from the model. A similar transition state for $\mathrm{H}-$ transfer to methyl was located, with somewhat lower $\Delta G_{298}^{\ddagger}$ values of $83 \mathrm{~kJ} \mathrm{~mol}^{-1}$ (gas phase) or $92 \mathrm{~kJ} \mathrm{~mol}^{-1}$ (PCM, $\mathrm{MeCN}) .^{35}$ Since the calculated activation barriers appear a little high to be consistent with the facile elimination of $\mathrm{CO}_{2}$ and $\mathrm{CH}_{4}$ observed experimentally, it is possible that more specific solvation effects that are not accounted for by the PCM method play a role. Further computational studies of these systems are in progress.

\section{Relation to catalytic carbonylation and water gas shift reactions}

Conventionally the methanol carbonylation and WGS reactions are depicted as occurring via coupled catalytic cycles in which $\operatorname{Ir}(\mathrm{I})$ reacts with either methyl iodide, to initiate the carbonylation cycle, or with HI to initiate the WGS cycle. ${ }^{12,17,22}$ Carbon dioxide then results from nucleophilic attack of water on an $\operatorname{Ir}(\mathrm{III})$ iodocarbonyl, $\left[\operatorname{Ir}(\mathrm{CO})_{2} \mathrm{I}_{4}\right]^{-}$or $\left[\operatorname{Ir}(\mathrm{CO})_{3} \mathrm{I}_{3}\right]$. The present study has demonstrated that $\mathrm{CO}_{2}$ formation can also occur by reaction of water with $\operatorname{Ir}(\mathrm{III})$ species that are part of the methanol carbonylation cycle, i.e. $\left[\operatorname{Ir}(\mathrm{CO})_{2} \mathrm{I}_{3} \mathrm{R}\right]^{-}(\mathrm{R}=\mathrm{Me}, \mathrm{COMe})$ and

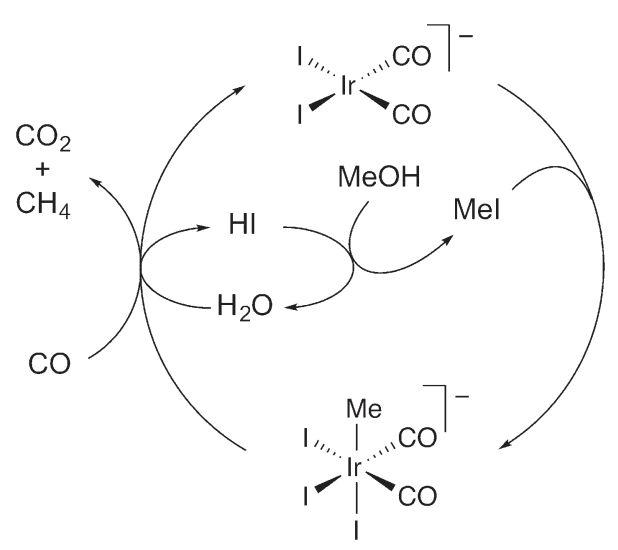

Scheme 4 Proposed cycle for combined $\mathrm{CO}_{2} / \mathrm{CH}_{4}$ formation under catalytic carbonylation conditions.
$\left.\left[\operatorname{Ir}(\mathrm{CO})_{3} \mathrm{I}_{2} \mathrm{Me}\right]\right)$. Scheme 4 shows a proposed catalytic cycle for the net conversion of methanol and carbon monoxide to methane and $\mathrm{CO}_{2}$ (eqn (3)). Oxidative addition of methyl iodide to $\left[\operatorname{Ir}(\mathrm{CO})_{2} \mathrm{I}_{2}\right]^{-}$proceeds in the same manner as for the methanol carbonylation cycle. The resulting Ir(III) methyl species then reacts with water and $\mathrm{CO}$ to release $\mathrm{CO}_{2}$ and methane and regenerate $\left[\operatorname{Ir}(\mathrm{CO})_{2} \mathrm{I}_{2}\right]^{-}$and $\mathrm{HI}$.

The proposed cycle shown in Scheme 4 provides a mechanism for combined $\mathrm{CO}_{2} / \mathrm{CH}_{4}$ formation (eqn (3)) without the intermediacy of $\mathrm{H}_{2}$ that would be generated by a conventional WGS reaction. Analogous cycles can be drawn in which water reacts with any of the Ir(III) methyl or acetyl complexes that participate in the methanol carbonylation mechanism. Indeed, under a high pressure of $\mathrm{CO}$, the reaction of $\left[\operatorname{Ir}(\mathrm{CO})_{2} \mathrm{I}_{3} \mathrm{Me}\right]^{-}$ with water shown in Scheme 4 might actually involve initial substitution of an iodide ligand by $\mathrm{CO}$ to give the more electrophilic neutral tricarbonyl, $\left[\operatorname{Ir}(\mathrm{CO})_{3} \mathrm{I}_{2} \mathrm{Me}\right]$. Likewise, $\mathrm{CO}_{2}$ formation could occur from an acetyl species (as shown in Scheme 3) after migratory CO insertion has occurred. Previously reported data from a pilot plant unit operating under steady state conditions show that the rates of $\mathrm{CO}_{2}$ and methane formation are very similar in $\mathrm{Ir} / \mathrm{Ru}$ catalysed reactions, at $c a .1 \%$ of the carbonylation rate. ${ }^{14}$ The close correspondence of $\mathrm{CO}_{2}$ and $\mathrm{CH}_{4}$ formation rates is consistent with a mechanism such as that shown in Scheme 4.

Since our results indicate that these $\mathrm{CO}_{2}$-forming reactions occur readily under mild conditions, an obvious question is why high selectivity to acetic acid is achieved in iridium-catalysed methanol carbonylation. The formation of $\mathrm{CO}_{2}$ and $\mathrm{CH}_{4}$ (eqn (3)) is favored thermodynamically with respect to acetic acid $\left(\Delta G_{298}=-57.7 \mathrm{~kJ} \mathrm{~mol}^{-1} \text { for } \mathrm{MeCO}_{2} \mathrm{H} \rightarrow \mathrm{CH}_{4}+\mathrm{CO}_{2}\right)^{36}$ so the selectivity is governed by kinetic considerations. Under process conditions, the key steps that facilitate turnover in the carbonylation cycle must compete effectively with the $\mathrm{CO}_{2}{ }^{-}$ forming reactions. Hence, the rates of migratory $\mathrm{CO}$ insertion (for Ir-methyl species) and elimination of acetyl iodide/acetic acid (for Ir-acetyl species) must exceed that of nucleophilic attack by water on coordinated CO. The different conditions used for the model reactions reported here and the catalytic process are presumably crucial in determining the outcomes. For two competing reactions, the one with lower activation energy will dominate at lower temperature but the Arrhenius relationship shows that the rate of a reaction with higher activation energy will increase more as the temperature is raised, and so it can become dominant at higher temperature. Since the temperature difference between the catalytic and model reactions here is $\sim 150{ }^{\circ} \mathrm{C}$, the relative reaction rates can be expected to be markedly different in the two systems. The reaction medium may also be important. In particular, the catalytic process operates under acidic conditions $\left(\mathrm{MeCO}_{2} \mathrm{H}-\mathrm{HI}-\mathrm{H}_{2} \mathrm{O}\right)$ that will influence the behaviour of hydroxycarbonyl species. Under acidic conditions, hydroxycarbonyl complexes are known to undergo dehydroxylation to reform a terminal carbonyl ligand whereas decarboxylation is often promoted by basic conditions. ${ }^{28,31,33,37,38}$ Hence, $\mathrm{CO}_{2}$ forming reactions may be inhibited in the reaction medium used for catalytic carbonylation. 
The overall rate of $\mathrm{CO}_{2}$ formation will result from a combination of the possible pathways and our data do not demonstrate whether one particular iridium species is the principal source of $\mathrm{CO}_{2}$. However, the neutral tricarbonyl, [ $\left.\operatorname{IrMe}(\mathrm{CO})_{3} \mathrm{I}_{2}\right]$ has been shown to be particularly reactive towards water and is also thought to be the dominant species in which migratory $\mathrm{CO}$ insertion occurs. Therefore it may be speculated that these two reactions of $\left[\operatorname{IrMe}(\mathrm{CO})_{3} \mathrm{I}_{2}\right]$ form a branching point in the mechanisms of acetic acid and $\mathrm{CO}_{2} / \mathrm{CH}_{4}$ formation and therefore determine selectivity. Analogous reactions of iridium acetyl species might also be responsible for the formation of other by-products like acetaldehyde, a precursor (via hydrogenation and carbonylation steps) to propionic acid that is reported to be present at levels of $290-1150 \mathrm{ppm}$ in the acetic acid product in pilot plant studies. ${ }^{14}$ Thus, nucleophilic attack by water on a terminal carbonyl ligand followed by proton transfer to acetyl would give a route to $\mathrm{CO}_{2} / \mathrm{MeCHO}$ formation. Although $\left[\operatorname{Ir}(\mathrm{CO})_{2} \mathrm{I}_{3}(\mathrm{COMe})\right]^{-}$reacts with water to release $\mathrm{CO}_{2}$ and $\mathrm{CH}_{4}$ (Scheme 2) the high $\mathrm{CO}$ pressure during catalytic carbonylation may inhibit the decarbonylation step proposed in Scheme 3 and allow acetaldehyde elimination from species such as $\mathbf{A}$, or $\mathbf{B}$.

\section{Conclusions}

This study has identified a pathway for the co-formation of $\mathrm{CO}_{2}$ and $\mathrm{CH}_{4}$ from iridium methyl and acetyl complexes that participate in iridium/iodide catalysed methanol carbonylation. Isotopic labeling experiments demonstrate that, on reaction with water under mild conditions, a terminal CO ligand of $\left[\operatorname{Ir}(\mathrm{CO})_{2} \mathrm{I}_{3}(\mathrm{COMe})\right]^{-}$is liberated as $\mathrm{CO}_{2}$ and decarbonylation of the acetyl moiety leads to loss of the methyl fragment as $\mathrm{CH}_{4}$. A mechanism involving nucleophilic attack by water on coordinated CO to form a hydroxycarbonyl ligand is implicated, followed by decarboxylation and methane elimination in stepwise or concerted fashion. Analogous reactions occur for $\left[\operatorname{Ir}(\mathrm{CO})_{2} \mathrm{I}_{3} \mathrm{Me}\right]^{-}, \quad\left[\operatorname{Ir}(\mathrm{CO})_{2}(\mathrm{NCMe}) \mathrm{I}_{2}(\mathrm{COMe})\right]$ and $\left[\operatorname{Ir}(\mathrm{CO})_{3} \mathrm{I}_{2} \mathrm{Me}\right]$, with the neutral species being an order of magnitude more reactive than the anions. A particularly notable reaction is that of $\left[\operatorname{Ir}(\mathrm{CO})_{3} \mathrm{I}_{2} \mathrm{Me}\right]$ which has been shown previously to undergo facile migratory $\mathrm{CO}$ insertion. The relative rates of methyl migration and attack by water on this complex may be significant in determining catalytic selectivity. The results show that the formation of $\mathrm{CO}_{2}$ and $\mathrm{CH}_{4}$ can occur in a coupled fashion, possibly from an intermediate such as $\mathbf{E}$ (Scheme 3), consistent with the similar rates of formation of these two gaseous by-products in catalytic reactions. Preliminary DFT calculations identified a transition state for direct $\mathrm{H}$ transfer from hydroxycarbonyl to methyl in E, resulting in concerted elimination of $\mathrm{CO}_{2}$ and $\mathrm{CH}_{4}$.

The observed reactions provide an alternative mechanism for methane formation in addition to the protonolysis and hydrogenolysis of iridium methyl complexes for which evidence has been presented previously. The new mechanism is closely related to that of the WGS reaction but does not involve the intermediacy of $\mathrm{H}_{2}$. It is likely that the gaseous by-products arise from multiple pathways during catalytic carbonylation and the relative contributions of the different routes likely depends on the process conditions employed. Nonetheless, the results presented in this paper provide further mechanistic insight into an important industrial process.

\section{Experimental}

Solvents were purified by distillation or using a column purification system. Methyl iodide (Sigma-Aldrich) was distilled over calcium hydride and stored at $5{ }^{\circ} \mathrm{C}$ in a foil-wrapped Schlenk tube under nitrogen and over mercury. Other reagents were used as supplied: $\mathrm{Ph}_{4}$ AsCl (Sigma-Aldrich), $\operatorname{IrCl}_{3} \cdot n \mathrm{H}_{2} \mathrm{O}$ (PMO Pty Ltd); carbon monoxide (BOC $\mathrm{CP}$ grade); ${ }^{13} \mathrm{C}$-enriched carbon monoxide (99\% ${ }^{13} \mathrm{C}$, Euriso-top). Standard Schlenk techniques and glassware were used for preparative reactions. The iridium compounds $\mathrm{Ph}_{4} \mathrm{As}\left[\operatorname{Ir}(\mathrm{CO})_{2} \mathrm{I}_{2}\right], \mathrm{Ph}_{4} \mathrm{As}\left[\operatorname{Ir}(\mathrm{CO})_{2} \mathrm{I}_{3} \mathrm{Me}\right]$, $\mathrm{Ph}_{4} \mathrm{As}\left[\operatorname{Ir}(\mathrm{CO})_{2} \mathrm{I}_{3}(\mathrm{COMe})\right],\left[\operatorname{IrMe}(\mathrm{CO})_{2} \mathrm{I}_{2}\right]_{2}$ (and their ${ }^{13} \mathrm{C}$ labelled analogues) were synthesised using published methods. ${ }^{20,22,39}$ ${ }^{1} \mathrm{H}$ NMR spectra were recorded on a Bruker AC250 instrument in pulsed Fourier transform mode, fitted with a Bruker B ACS-60 sample changer, and using solvent as internal reference. GC and GC-MS measurements were made using PerkinElmer Autosystem XL and TurboMass instruments respectively (capillary column PE-1, $60 \mathrm{~m} \times 0.320 \mathrm{~mm}, d_{\mathrm{f}}=5.00 \mu \mathrm{m}$; temperature program $0{ }^{\circ} \mathrm{C}$ for $5 \mathrm{~min}$, raise $10^{\circ} \mathrm{min}^{-1}$ up to $200{ }^{\circ} \mathrm{C}$, $200{ }^{\circ} \mathrm{C}$ for $5 \mathrm{~min}$ ).

Solution-phase infrared spectra were recorded on a Mattson Genesis FTIR spectrometer controlled by WinFirst software using a $\mathrm{CaF}_{2}$ liquid cell ( $0.5 \mathrm{~mm}$ pathlength). For kinetic experiments, the cell was maintained at the desired temperature by use of a thermostatted water jacket and circulating water bath. In a typical experiment, a solution of water at the appropriate concentration in MeCN or THF was prepared in a $5 \mathrm{~cm}^{3}$ graduated flask. A portion of this solution was transferred to the IR cell to record a background spectrum. The reaction was then initiated by dissolving the iridium compound ( $c a .5 \mathrm{mg}$ ) in $1 \mathrm{~cm}^{3}$ of the water-containing solution. After thorough mixing, a portion of the resulting solution was transferred to fill the pre-equilibrated IR cell. IR spectra were recorded at programmed time-intervals under computer control. Absorbance vs. time data were extracted for analysis using Kaleidagraph curve-fitting software. Observed rate constants are tabulated in the ESI. $\neq$

Reactions of $\left[\operatorname{Ir}(\mathrm{CO})_{3} \mathrm{I}_{2} \mathrm{Me}\right]$ with water were monitored under CO pressure using a cylindrical internal reflectance (CIR) cell comprising an autoclave (Parr) modified (by SpectraTech) to accommodate a crystalline silicon CIR rod as described by Moser. $^{40,41}$ Spectra were recorded using a Perkin-Elmer 1710 FTIR spectrometer fitted with an MCT detector. In a typical experiment, $\left[\operatorname{Ir}(\mathrm{CO})_{2} \mathrm{I}_{2} \mathrm{Me}\right]_{2}(160 \mathrm{mg})$ was dissolved in a $3: 1$ mixture of $\mathrm{CH}_{2} \mathrm{Cl}_{2}-\mathrm{THF}\left(8 \mathrm{~cm}^{3}\right)$ containing the required concentration of water. The resulting solution was transferred to the CIR cell (maintained at $23^{\circ} \mathrm{C}$ ) that was then sealed and 
purged three times with $\mathrm{CO}$. The cell was then pressurized to 20 bar $\mathrm{CO}$ with continuous stirring to generate $\left[\operatorname{Ir}(\mathrm{CO})_{3} \mathrm{I}_{2} \mathrm{Me}\right]$ (2156, 2116 and $2098 \mathrm{~cm}^{-1}$ ) as described previously. ${ }^{20,26}$ IR spectra were recorded at intervals under these conditions to monitor the evolution of $\nu(\mathrm{CO})$ absorptions with time. After completion of the reaction a sample of the cell head-space was collected by venting into a glass tube. A $300 \mu \mathrm{l}$ sample was analysed by GC-MS (split mode 1/20, $0{ }^{\circ} \mathrm{C}$ ). Experiments using $\left[\operatorname{Ir}(\mathrm{CO})_{2} \mathrm{I}_{2}\left(\mathrm{CD}_{3}\right)\right]_{2}$ and $\left[\operatorname{Ir}\left({ }^{13} \mathrm{CO}\right)_{2} \mathrm{I}_{2} \mathrm{Me}\right]_{2}$ were conducted using the same procedure.

Density functional theory (DFT) calculations were performed using the Gaussian 09 program package, ${ }^{42}$ compiled using the Portland compiler (version 8.0-2) on an EMT64 architecture using Gaussian-supplied versions of BLAS and ATLAS. $^{43,44}$ All calculations employed the B3LYP functional ${ }^{45}$ with Stuttgart/Dresden pseudopotentials ${ }^{46,47}$ on iridium and iodine and the $6-311 \mathrm{G}^{* *}$ basis set on all other atoms. ${ }^{48,49}$ This basis set/functional combination has resulted in (semi-) quantitative agreement with experiment in previous work. ${ }^{50-52} \mathrm{Geo}-$ metry optimizations were performed using the default settings. Frequency calculations confirmed the absence of imaginary frequencies for minimum energy structures and the presence of a single imaginary frequency for transition state structures. Visual inspection showed this frequency to correspond to the reaction coordinate for $\mathrm{H}$-transfer. Medium effects were modeled using the PCM method, ${ }^{53,54}$ with acetonitrile as solvent. Cartesian coordinates and relative energies of optimised structures and are provided in the ESI.†

\section{Acknowledgements}

We thank the EPSRC and BP Chemicals Limited for funding this research.

\section{References}

1 D. Forster, Adv. Organomet. Chem., 1979, 17, 255-267.

2 T. W. Dekleva and D. Forster, Adv. Catal., 1986, 34, 81-130.

3 M. J. Howard, M. D. Jones, M. S. Roberts and S. A. Taylor, Catal. Today, 1993, 18, 325-354.

4 P. M. Maitlis, A. Haynes, G. J. Sunley and M. J. Howard, J. Chem. Soc., Dalton Trans., 1996, 2187-2196.

5 N. Yoneda, S. Kusano, M. Yasui, P. Pujado and S. Wilcher, Appl. Catal., A, 2001, 221, 253-265.

6 P. Torrence, in Applied Homogeneous Catalysis with Organometallic Compounds, ed. B. Cornils and W. A. Herrmann, Wiley-VCH, Weinheim, 2nd edn, 2002, vol. 1, pp. 104-136.

7 P. Maitlis and A. Haynes, in Metal-Catalysis in Industrial Organic Processes, ed. P. Maitlis and G. P. Chiusoli, RSC, 2006, pp. 114-162.

8 G. E. Morris, in Mechanisms in Homogeneous Catalysis; a Spectroscopic Approach, ed. B. T. Heaton, Wiley-VCH, Weinheim, 2005, pp. 195-230.
9 A. Haynes, in Catalytic Carbonylation Reactions, ed. M. Beller, Springer, Berlin, 2006, vol. 18, pp. 179-205.

10 A. Haynes, in Comprehensive Organometallic Chemistry III, ed. R. H. Crabtree and D. M. P. Mingos, Elsevier, 2006, vol. 7, pp. 427-444.

11 P. Kalck and P. Serp, in Iridium Complexes in Organic Synthesis, ed. L. A. Oro and C. Claver, Wiley-VCH, Weinheim, 2009, pp. 195-209.

12 A. Haynes, Adv. Catal., 2010, 53, 1-45.

13 F. E. Paulik and J. F. Roth, Chem. Commun., 1968, 1578.

14 G. J. Sunley and D. J. Watson, Catal. Today, 2000, 58, 293307.

15 J. H. Jones, Platinum Met. Rev., 2000, 44, 94-105.

16 E. C. Baker, D. E. Hendriksen and R. Eisenberg, J. Am. Chem. Soc., 1980, 102, 1020-1027.

17 D. Forster, J. Chem. Soc., Dalton Trans., 1979, 1639-1645.

18 D. Forster and T. C. Singleton, J. Mol. Catal., 1982, 17, 299314.

19 T. Ghaffar, J. P. H. Charmant, G. J. Sunley, G. E. Morris, A. Haynes and P. M. Maitlis, Inorg. Chem. Commun., 2000, 3, 11-12.

20 A. Haynes, P. M. Maitlis, G. E. Morris, G. J. Sunley, H. Adams, P. W. Badger, C. M. Bowers, D. B. Cook, P. I. P. Elliott, T. Ghaffar, H. Green, T. R. Griffin, M. Payne, J. M. Pearson, M. J. Taylor, P. W. Vickers and R. J. Watt, J. Am. Chem. Soc., 2004, 126, 2847-2861.

21 M. Volpe, G. Wu, A. Iretskii and P. C. Ford, Inorg. Chem., 2006, 45, 1861-1870.

22 S. Gautron, N. Lassauque, C. Le Berre, L. Azam, R. Giordano, P. Serp, G. Laurenczy, J.-C. Daran, C. Duhayon, D. Thiébaut and P. Kalck, Organometallics, 2006, 25, 5894-5905.

23 A. Haynes, A. J. H. M. Meijer, J. R. Lyons and H. Adams, Inorg. Chem., 2009, 48, 28-35.

24 In view of the approximate pseudo-first order kinetic behaviour observed, we do not assign any mechanistic significance to the non-zero intercept in the absence of further evidence.

25 J. M. Pearson, A. Haynes, G. E. Morris, G. J. Sunley and P. M. Maitlis, J. Chem. Soc., Chem. Commun., 1995, 10451046.

26 T. Ghaffar, H. Adams, P. M. Maitlis, G. J. Sunley, M. J. Baker and A. Haynes, Chem. Commun., 1998, 1023-1024.

27 A. Haynes, P. M. Maitlis, I. A. Stanbridge, S. Haak, J. M. Pearson, H. Adams and N. A. Bailey, Inorg. Chim. Acta, 2004, 357, 3027-3037.

28 P. I. P. Elliott, C. E. Haslam, S. E. Spey and A. Haynes, Inorg. Chem., 2006, 45, 6269-6275.

29 For example, for $\left[\operatorname{Ir}(\mathrm{CO})_{3} \mathrm{I}_{2} \mathrm{Me}\right.$ ] (in $3: 1 \mathrm{CH}_{2} \mathrm{Cl}_{2}-\mathrm{THF}, 1.04 \mathrm{M}$ $\left.\mathrm{H}_{2} \mathrm{O}, 23^{\circ} \mathrm{C}\right) k_{\text {obs }}=1.55 \times 10^{-3} \mathrm{~s}^{-1}$ compared with $3.64 \times$ $10^{-5} \mathrm{~s}^{-1}$ for $\left[\operatorname{Ir}(\mathrm{CO})_{2} \mathrm{I}_{3}(\mathrm{COMe})\right]^{-}$(in MeCN, 0.56 M H $\mathrm{H}_{2} \mathrm{O}$, $\left.25^{\circ} \mathrm{C}\right)$.

30 A. J. Deeming and B. L. Shaw, J. Chem. Soc. A, 1969, 443446.

31 A. J. Deeming and G. P. Proud, J. Organomet. Chem., 1986, 301, 385-390. 
32 E. Gutierrez-Puebla, A. Monge, M. C. Nicasio, P. J. Perez, M. L. Poveda, L. Rey, C. Ruiz and E. Carmona, Inorg. Chem., 1998, 37, 4538-4546.

33 M. J. Fernandez, M. J. Rodriguez and L. A. Oro, J. Organomet. Chem., 1992, 438, 337-342.

34 I. I. Padilla-Martinéz, M. L. Poveda and E. Carmona, Organometallics, 2002, 21, 93-104.

35 For comparison, a transition state was also located for reductive elimination of methane from intermediate $\mathbf{D}$, giving a $\Delta G_{298}^{\ddagger}$ of $88 \mathrm{~kJ} \mathrm{~mol}^{-1}$ (gas phase).

36 NIST Chemistry WebBook, NIST Standard Reference Database Number 69, ed. P. J. Linstrom and W. G. Mallard, National Institute of Standards and Technology, Gaithersburg, MD, http://webbook.nist.gov, (retrieved June 13, 2013).

37 K. Bowman, A. J. Deeming and G. P. Proud, J. Chem. Soc., Dalton Trans., 1985, 857-860.

38 M. A. Bennett, G. B. Robertson, A. Rokicki and W. A. Wickramasinghe, J. Am. Chem. Soc., 1988, 110, 70987105.

39 S. Gautron, R. Giordano, C. Le Berre, J. Jaud, J.-C. Daran, P. Serp and P. Kalck, Inorg. Chem., 2003, 42, 5523-5530.

40 W. R. Moser, J. E. Cnossen, A. W. Wang and S. A. Krouse, J. Catal., 1985, 95, 21-32.

41 W. R. Moser, B. J. Marshik-Guerts and S. J. Okrasinski, J. Mol. Catal. A: Chem., 1999, 143, 57-69.

42 M. J. Frisch, G. W. Trucks, H. B. Schlegel, G. E. Scuseria, M. A. Robb, J. R. Cheeseman, G. Scalmani, V. Barone, B. Mennucci, G. A. Petersson, H. Nakatsuji, M. Caricato, X. Li, H. P. Hratchian, A. F. Izmaylov, J. Bloino, G. Zheng, J. L. Sonnenberg, M. Hada, M. Ehara, K. Toyota, R. Fukuda, J. Hasegawa, M. Ishida, T. Nakajima, Y. Honda, O. Kitao, H. Nakai, T. Vreven, J. A. Montgomery, Jr., J. E. Peralta, F. Ogliaro, M. Bearpark, J. J. Heyd, E. Brothers, K. N. Kudin, V. N. Staroverov, R. Kobayashi, J. Normand,
K. Raghavachari, A. Rendell, J. C. Burant, S. S. Iyengar, J. Tomasi, M. Cossi, N. Rega, N. J. Millam, M. Klene, J. E. Knox, J. B. Cross, V. Bakken, C. Adamo, J. Jaramillo, R. Gomperts, R. E. Stratmann, O. Yazyev, A. J. Austin, R. Cammi, C. Pomelli, J. W. Ochterski, R. L. Martin, K. Morokuma, V. G. Zakrzewski, G. A. Voth, P. Salvador, J. J. Dannenberg, S. Dapprich, A. D. Daniels, Ö. Farkas, J. B. Foresman, J. V. Ortiz, J. Cioslowski and D. J. Fox, Gaussian 09, Revision C.01, Gaussian, Inc., Wallingford, CT, 2009.

43 R. C. Whaley and A. Petitet, Software: Pract. Exper., 2005, 35, 101-121.

44 R. C. Whaley, A. Petitet and J. J. Dongarra, Parallel Comput., 2001, 27, 3-35.

45 A. D. Becke, J. Chem. Phys., 1993, 98, 5648-5652.

46 X. Cao and M. Dolg, J. Chem. Phys., 2001, 115, 7348-7355.

47 A. Nicklass, M. Dolg, H. Stoll and H. Preuss, J. Chem. Phys., 1995, 102, 8942-8952.

48 A. D. McLean and G. S. Chandler, J. Chem. Phys., 1980, 72, 5639-5648.

49 R. Krishnan, J. S. Binkley, R. Seeger and J. A. Pople, J. Chem. Phys., 1980, 72, 650-654.

50 S. P. Foxon, C. Green, M. G. Walker, A. Wragg, H. Adams, J. A. Weinstein, S. C. Parker, A. J. H. M. Meijer and T. J. A, Inorg. Chem., 2012, 51, 463-471.

51 H. Ahmad, A. J. H. M. Meijer and J. A. Thomas, Chem.-Asian J., 2011, 6, 2339-2351.

52 A. B. Wragg, S. Derossi, T. L. Easun, M. W. George, X.-Z. Sun, F. Hartl, A. H. Shelton, A. J. H. M. Meijer and M. D. Ward, Dalton Trans., 2012, 41, 10354-10371.

53 B. Mennucci and J. Tomassi, J. Chem. Phys., 1997, 106, 5151-5158.

54 M. Cossi, V. Barone, B. Mennucci and J. Tomasi, Chem. Phys. Lett., 1998, 286, 253-260. 